confusion of doctrines immovable ideas and true laws as to render chemistry an exact science, for it lies now on mathematical truth."

Cannizzaro replied to the congratulations in an interesting speech, which we hope to refer to more fully in a future issue. In the course of his remarks he referred to the confusion and uncertainty which dominated chemistry between $1850-5 \mathrm{I}$ on the criterions for determining atomic weights and on the value of formula, giving an account of the attempts made by others and himself to reduce chemical notation to law and order.

He afterwards referred to the subject of the division of pure science from teaching. He cited De Candolle's book, "Histoire des Sciences et de Savants," to the effect that the two functions of teaching and contributing to the science progress are to be separated. De Candolle hoped for the time when academies would be formed by free investigators. Cannizzaro is of contrary opinion, and dwelt upon the utility of teaching. He said : " $\mathrm{Had}$ I not been a teacher, my publications would not have appeared, and I should have continued to disseminate science of new carbonium compounds. I bring here Lord Kelvin's example, who, in his last jubilee, spoke of the utility he had found by the continued conferences with his scholars."

In speaking upon chemical laboratories, Cannizzaro expressed the opinion that the Director ought to dwell in the same building where the laboratories are situated. He thinks the German type of laboratory the best of all ; for he said : "The chief must be considered in a scientific institute as the first, and more useful instrument."

Cannizzaro concluded by referring to the large sum obtained by subscription on occasion of his jubilee, and devoting the remainder of it to the extension of the Roman laboratories.

The celebration was concluded amid great enthusiasm and prolonged applause.

A. Miolati

\section{THE FINAL ENTOMBMENT OF PASTEUR.}

THE remains of Pasteur, which for nearly fifteen months have been lying at Notre Dame, were on Saturday, Dec. 26, borne in solemn procession to their last resting-place at the Pasteur Institute, where a crypt worthy to hold the ashes of that great benefactor of the human race has been constructed. The subjoined report, slightly abridged from the Times, shows that the ceremony of the final entombment was an impressive one and that representatives of British science were among those who, by their presence and their words, testified to the high regard in which the name of Pasteur is held.

As at the original funeral, there were present a number of eminent men of science and thinkers, both French and foreign, and the ceremony derived additional grandeur from the gathering which witnessed the final interment. The man whose ashes lie in this tomb erected by filial piety and universal admiration is depicted in a sentence from his reception speech at the Academy which the architect has inscribed on the stone: "Heureux celu qui porte en soi un dieu, un idéal de beauté, et qui lui obéitidéal de l'art, idéal de la science, idéal de la patrie, idéal des vertus de l'évangile." The English deputation included Sir Joseph Lister, President of the Royal Society, Sir Dyce Duckworth, Sir John Evans, and Sir William Priestley. Dr. Metchnik off represented Russia, and Dr. van Hoorn IInlland. M. Méline and M. Rambaud represented the Government, and II. Brisson, a number of ex-Ministers, Senators and Deputies, many members of the Institute and the Prefects of Police and of the Seine were among those present.

There was, first of all, a service at Notre Dame, attended by the family and the staff of the Pasteur Institute, who then, with the archpriest, followed the hearse to the Institute. A crowd had collected outside, and amid an impressive silence every head was bared as the coffin was carried up the steps through the grand vestibule and down to the crypt, which was decorated by the wreaths sent by English, Russian, and French societies and

$$
\text { NO. I } 418 \text {, VOL. 55] }
$$

institutions. The parish priest pronounced the last prayers as the coffin was deposited in its last resting-place in the presence of the family. They then remounted the steps to the entrance of the crypt, where all the spectators were stationed, and M. I. B. Pasteur, addressing the Council of the Institute, said: "I entrust to you this tomb which we have raised to our father in this Institute which he loved so dearly. We beg you to preserve it carefully." M. Bertrand, President of the Council, thanked the family for their pious idea, thanks to which, he said, the pilgrims who would come from all parts of the world to honour the memory of the great benefactor of mankind would be able to meditate by his tomb. M. Rambaud, Minister of Education, next delivered a warm eulogium. "As those tombs of saints," he said, "on which people saw prodigies accom. plished, that of Pasteur will be encircled by a halo of miracles. At every discovery beneficial to mankind, at every ray of scientific glory which will be added to the aureole of France, the gratitude of the country and of the universe will flow to this building, henceforth august in the annals of science, as to the source of all ulterior progress." M. Baudin, President of the Municipality, was the next speaker, and an address by $M$. Legouvé, the father of the French Academiy, was read by M. Gaston Boissier.

Sir Joseph Lister then said: "Je suis chargé de représenter la Société Royale de Londres, le Collége Royal des Chirurgiens d'Angleterre et la Société Médico-Chirurgicale de Londres. Aussi j'ai fait déposer, de la part de l'Institut Britannique de la Médecine Préventive, fille de l'Institut Pasteur, une couronne ici. Il y a quatre ans, à l'occasion du jubilé de Monsieur Pasteur, j'ai eu le suprême honneur de lui présenter, au nom de la Médecine et de la Chirurgie du monde entier, l'hommage de leur reconnaissance. Aujourd'hui j'assiste à ses funérailles! Cette cérémonie est noble et imposante, digne de la mémoire de notre vénéré maître. Mais elle nous remplit d'une profonde tristesse, puisqu'elle nous rappelle que cette grande lumiere de la science, si ardente et si claire, est éteinte; que ce caractère, si noble et si aimable, a disparu de notre monde."

Sir Dyce Duckworth spoke as follows: "Au nom du Col. lége Royal des Médecins de Londres, j'ai l'honneur de témoigner la vive sympathie avec laquelle les médecins d'Angleterre s'associent à cette touchante cérémonie. Je porte l'hommage de nos confrères à ce grand génie créateur, à ce noble caractère de Louis Pasteur. Pour nous il est un des prophètes de la science, il en est un des avant-coureurs les plus éclairés et les plus intrépides. Vénérons ensemble ce bienfaiteur de l'humanité! Vénérons ce Chrétien loyal et convaincu, dont la foi a résisté à toutes les influences matérialisantes de ses études! Que l'œuvre de Pasteur, dont les cendres reposeront désormais dans ce sol consacré par son travail, reste une des gloires impérissables de la France et du monde!"

Sir W. Priestley said the two Scottish Universities of Edinburgh and St. Andrews appointed him as their representative, in token of respect for the memory of one who had done so much to advance the interests of science, and who had conferred such signal benefits on mankind. He remarked that Pasteur not only made great discoveries himself-discoveries which had conterred priceless benefits on man and on the lower animalsbut he opened up new and hitherto unexplored paths in the field of science, the horizon of which was almost unlimited.

M. Cornu, for the Academy of Sciences, M. Bergeron, for the Academy of Medicine, M. Perrot, for the Normal School, M. Louis Passy, for the Agricultural Society, M. Tissier, for the medical students, and M. Duclaux, director of the Pasteur Institute, also spoke. A feeling of restrained emotion prevailed during the entire ceremony, at the conclusion of which the spectators passed respectfully before the tomb and greeted the widow and family of the illustrious investigator.

\section{NOTES.}

WE deeply regret to have to record the death of Prof. Emil Du Bois-Reymond, the eminent professor of physiology in the University of Berlin. Before his burial in the French cemetery in Berlin, on Tuesday, addresses were delivered in the Physiological Institute, of which Du Bois-Reymond was the founder. The Emperor and the Empress Frederick have telegraphed expressions of condolence to the widow and relatives of the deceased. 